Revista Brasileira de Farmacognosia Brazilian Journal of Pharmacognosy 21(4): 568-574, Jul./Aug. 2011

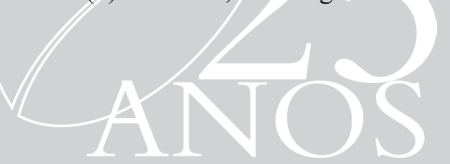

Article

Received 3 Aug 2010

Accepted 30 Dec 2010

Available online 10 Jun 2011

Keywords:

"jurubeba"

medicinal plant

morpho-anatomy

Solanaceae

Solanum subg. Leptostemonum

ISSN $0102-695 \mathrm{X}$

doi: $10.1590 / \mathrm{S} 0102-695 \mathrm{X} 2011005000101$

\section{A pharmacobotanical study of vegetative organs of Solanum torvum}

\author{
Kiriaki Nurit-Silva, Rafael Costa-Silva, Victor P. M. Coelho, \\ Maria de Fátima Agra
}

\author{
Laboratorio de Tecnologia Farmacêutica Prof. Delby Fernandes de \\ Medeiros, Seção de Botânica, Universidade Federal da Paraíba, Brazil.
}

\begin{abstract}
In this work, a morpho-anatomical study of the leaves, stems and roots of Solanum torvum Sw. was performed with the objective of providing a macroscopical and microscopical morphodiagnosis for its characterization. The species is popularly called "jurubeba-branca" in the Northeastern Brazil and is used in folk medicine to treat liver diseases, tuberculosis, and as antianemic. Anatomical studies were done by paradermic sections of the leaf blade (adaxial and abaxial surfaces), and cross sections of leaves (blade and petiole), stems and roots. The sections were clarified and stained with safranin and/ or astrablue, observed and photographed on light microscope. Histochemical tests were carried out in cross sections of leaves, stems and roots and assayed for specific reagents. The leaves are chartaceous, ovate to elliptic, with lobed margins, oblique at the base. The leaf is amphistomatic with anisocytic and anomocytic stomata simultaneously, and the epidermal cells, in face view, have anticlinal walls sinuate on the upper surface and wavy on the lower surface. The mesophyll is dorsiventral; the midrib has a central bicollateral vascular bundle; and the petiole has three or fourone. The stem shows external phloem, xylem, internal phloem and a parenchymatic pith. The root is axial and striate longitudinally and the secondary xylem is a massive cylinder. The macroscopical and microscopical vegetative characters constitute a set of diagnostic parameters to the studied species.
\end{abstract}

\section{Introduction}

Solanum L. is the most representative of the Solanaceae family with about 1400 species and cosmopolitan distribution (Bohs, 2005). The genus is known for its economic importance having species used as food, like "potato" (Solanum tuberosum L.), tomato (S. lycopersicum L.), egg-plant (S. melongena (Mill.) Dunal) etc., as well as species with pharmacological interest like $S$. dulcamara (Moench) Dumort and $S$. sodomeum $\mathrm{L}$., for examples that showed anti-neoplasic activity (Kupchan et al., 1965; Cham et al., 1987; Cham \& Meares, 1987).

Solanum torvum Sw. is native of Caribbean belonging to Solanum sect. Torva Nees, with wide distribution and found in tropical regions of the world (D'Arcy, 1973). In Brazil, it is found in various regions of the country and popularly called "jurubeba" and "jurubeba-branca" (Agra \& Bhattacharyya, 1999) and its roots are used in folk medicine in liver diseases, tuberculosis, and as anti-anemic as a substitute for $S$. paniculatum L. ("jurubeba-verdadeira").
Solanum sect. Torva belonging to the subgenus Leptostemonum has about forty species with wide distribution in Americas, Africa, Asia, New Guinea and Pacific (Nee, 1999). In Brazil, according to Agra (2007), the section comprises about eleven species and some of them have restricted distribution like S. metrobotryon Dunal. Species of this section are characterized by a plurifoliate sympodial units, branched inflorescence, and glabrous and juicy fruits.

Solanum torvum contains alkaloids like jurubine, paniculogenin (Schreiber \& Ripperger, 1968), solasodine, solasodien, torvogenin (Dopke et al., 1975), steroids like sisalogenin, torvogenin and sisalogenone (Mendes et al., 1970), and also flavonoids, such as torvanol A and a torvosíde H (Arthan et al., 2002), and sapogenin, inter alia (Cuervo et al., 1991).

The methanolic extracts of leaves and fruits of $S$. torvum showed biological activities such as bactericidal (Chah et al., 2000; Wiart et al., 2004), fungicidal (Chah et al., 2000) and as antiviral, against the herpes vírus type I (Arthan et al., 2002). The aqueous extract from fruits showed anti-hypertensive 
activity (Nguelefack et al., 2007).

In this work, a morpho-anatomical study of the vegetative organs of $S$. torvum has been carried out with the objective of providing a macroscopical and microscopical morphodiagnosis for its characterization which forms a part of a project of pharmacognostic studies of Solanum species used as medicinal plants in Brazil (Basílio et al., 2007; Nurit-Silva \& Agra, 2005; Nurit-Silva et al., 2007a,b).

\section{Material and Methods}

The macroscopical analyses were carried out with fresh samples of Solanum torvum Sw. as well as specimens from the Herbarium Prof. Lauro Pires Xavier (Agra 1477, Agra 2236, Agra \& Bhattacharyya 1248, Agra \& Góis 520, Agra \& Góis 1295, Agra \& Nurit 6758, Grisi 157, Grisi 236) complemented by field observations. The study was done in the vegetative organs, helped by binocular stereomicroscope. The microscopical analyses were done by paradermic sections of leaf blades on upper and lower surfaces, and by cross sections manually supported by medulla of petiole of Cecropia sp. following the usual methodology. It was carried out in adult leaves (blade and petiole) from the $5^{\text {th }}$ node, and fragments of stem from the apical portion, and secondary roots from median and apical portions of small caliber. The sections were cleared with sodium hypochlorite $20 \%$, neutralized with acetic water $0.2 \%$, washed in distilled water. The epidermal tissue was stained in a solution of safranin and the mesophyll in a solution of astrablue, and were mounted in slide with glycerin $50 \%$. The anatomical characterizations of epidermis and mesophyll were based on Metcalfe \& Chalk (1979), and the classification of stomata is according to Wilkinson (1979).

Photomicrographs of the indument of trichomes were made through scanning electron microscopy (SEM). Portions of 5.0 by $2.0 \mathrm{~mm}$ wide of the leaf blade were dehydrated in graded ethanol series, mounted on stubs, coated with gold and analyzed in scanning electron microscope (SEM), Jeol JSM6300.

The histochemical tests were carried out in cross sections of leaves, stems and roots by treatment with the specific reagents: Sudan III (Jensen, 1962) for cuticle and cutinized layers; acidified phloroglucinol (Johansen, 1940) for lignified and suberized elements and a solution of lugol for starch grains (Berlyn \& Miksche, 1976). The anatomical structures were observed and photographed with Olympus model CX31 light microscope and Olympus PM-BP35 camera, respectively.

\section{Results}

Macroscopical morphodiagnosis
The leaf is subinerm with sparse and conical prickles, slightly recurved at the apex, 4.0-6.0 $\mathrm{mm}$ long, with chartaceous, ovate to ovate-elliptic and lobed or repand blades acute at apex, oblique or obtuse at the base, 8.5-25.0 x 8.0-24.0 cm, scabrous and tomentose on adaxial and abaxial surfaces, respectively, with a cylindrical and tomentose petiole. The stem and branches are cylindrical and lenticeled, green and tomentose in young plant to glabrescent and brown in adult plant. The root is axial with the main root having about $30 \mathrm{~cm}$ length, externally light-brown with longitudinal striations.

\section{Microscopical morphodiagnosis}

\section{Leaf}

The blade, in face view, is amphistomatic having anisocytic and anomocytic stomata. The epidermal cells have sinuous anticlinal walls on the adaxial surface (Figure 1A) and waved on the abaxial surface (Figure 1D). In cross section, the epidermis is 1-layered with rounded cells (Figure 3A) and the stomata are located on the same level as the other epidermal cells. Porrect-stellate trichomes occur on both surfaces and they are sessile with reduced midpoint (Figures 1E, 2A) or stalked (Figures 1C, $1 \mathrm{~F}, 2 \mathrm{~B})$.

The mesophyll is dorsiventral (Figure 3A), with palisade parenchyma unisseriate, and 4-5 layered spongy parenchyma, occupying about $60 \%$ of the mesophyll, with sparse idioblasts of sand crystals.

The midrib, in cross section, shows contour slightly biconvex at the apical portion (Figure 3B) to strongly biconvex at median and basal portions (Figure 3C). The epidermis is 1-layered and is followed by an angular collenchyma, 4-7 layered, and by the ground parenchyma. The vascularization is bicollateral and is composed of only one central bundle, in arc shape, on apical portion, which gradually becomes "U" shaped toward the median to basal portions. Idioblasts of sand crystals were observed in the external phloem. The lignified xylem was confirmed in sections of midrib (Figure 5A), and also in sections of petiole.

The petiole is circular in cross section at the median and apical portions (Figure 3D) to slightly arched at the base (Figure 3E). The epidermis is 1-layered with sparse porrect-stellate trichomes. The angular collenchyma is 7-10 layered (Figure 3D-E) followed by the ground parenchyma with sparse idioblasts of sand crystals. The vascularization is bicollateral, similar to the pattern found in the midrib, differing by the number and shape of bundles having a set of 3 to 4 central bundles in shape of "U" (Figure 3D). At the apical (Figure 3D) and median portions were observed two smaller and circular accessories 


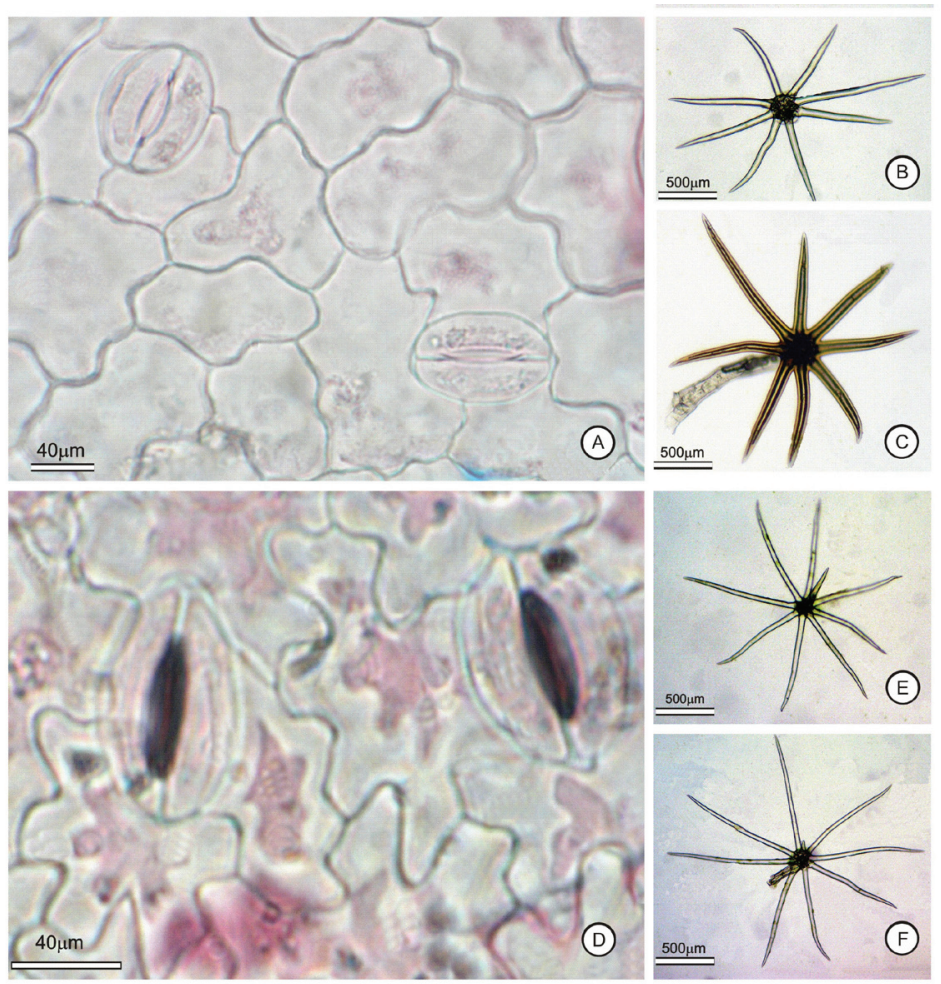

Figure 1. Solanum torvum Sw. (Agra \& Nurit 6758). A e D. Epidermis and stomata (anisocytic and anomocytic), in face view: A. Adaxial surface with sinuous anticlinal walls; B. Sessile porrect-stellate trichome; C. stalked porrect-stellate trichome; D. Abaxial surface with waved anticlinal walls; E-F. Porrect-stellate trichomes.
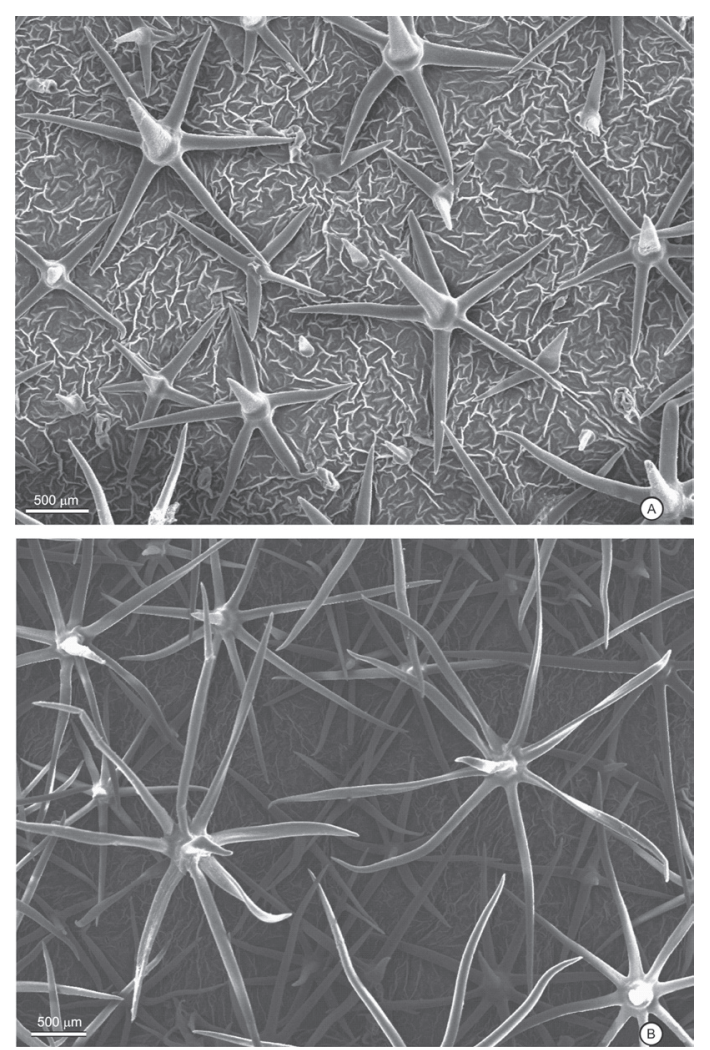

Figure 2. Solanum torvum Sw. (Agra \& Nurit 6758). SEM photographs. A, B. Indument of the leaves: A. Adaxial surface, sessile porrect-stellate trichomes, with reduced midpoint; B. Abaxial surface, stalked porrect-stellate trichomes. 

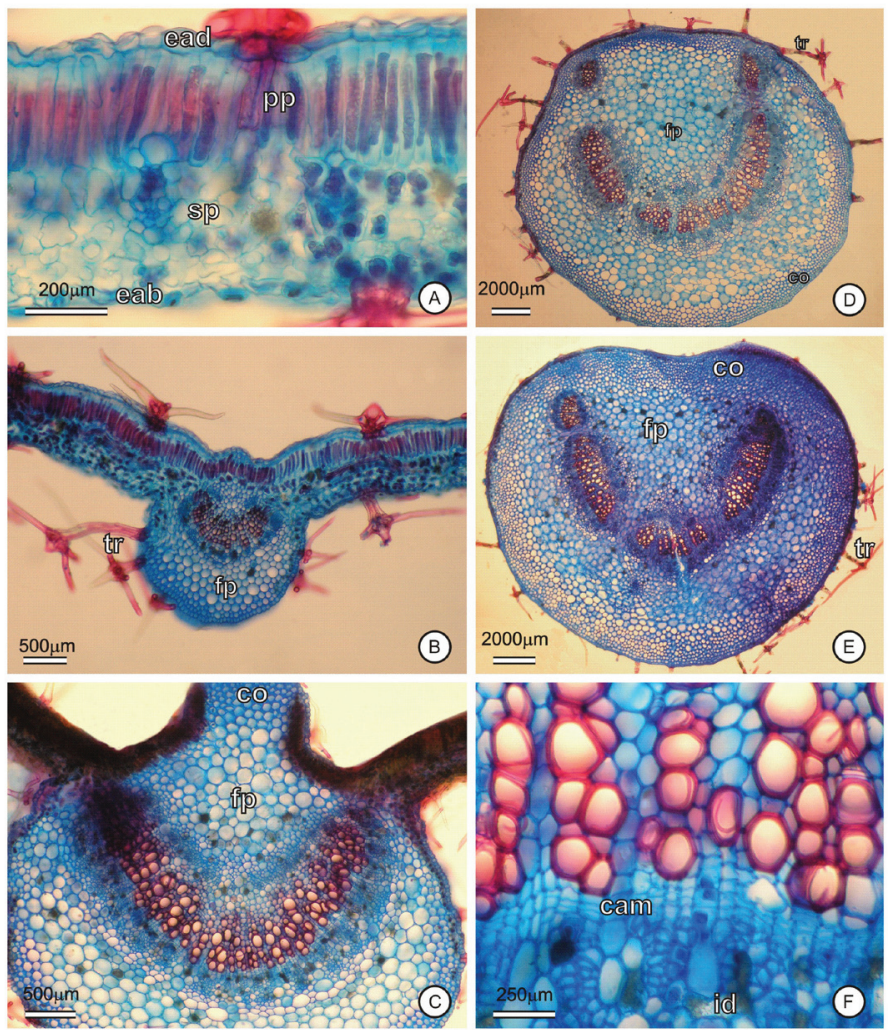

Figure 3. A-C. Leaf blade in cross section: A. Dorsiventral mesophyll; B-C. Bicollateral bundle of the midrib in shape of arc: B. Apical portion, C. Median portion. D-E. Petiole, in cross section, bicollateral vascular bundle in shape of "U": D. Apical portion; E. Basal portion; F. Detail of a vascular bundle. Abbreviations: cam: cambium, co: collenchyma, eab: abaxial surface of the epidermis, ead: adaxial surface of the epidermis, fp: ground parenchyma, id: idioblast, pp: palisade parenchyma; sp: spongy parenchyma, tr: porrect-stelatte trichome.
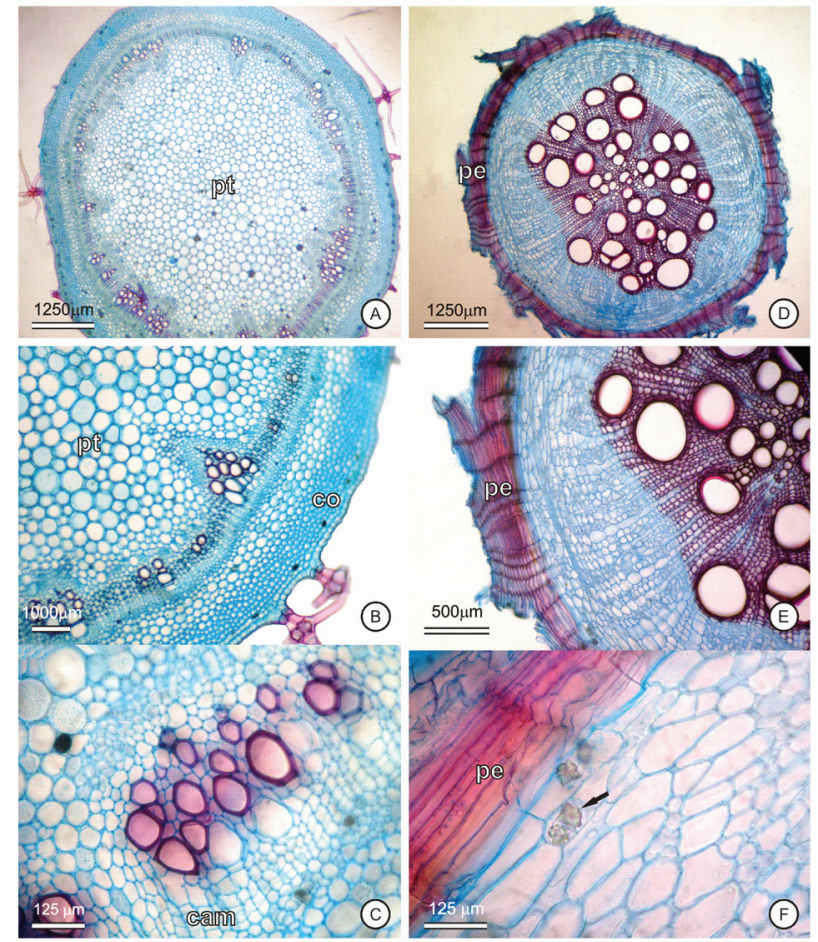

Figure 4. Solanum torvum Sw. (Agra \& Nurit 6758). A-C. Stem, in secondary growth, in cross section: A. General view; B. Detail; C. Detail of vascular bundle. D-F. Root, in cross section: D, E. General view, in secondary growth; F. Detail of idioblasts with druses, below the periderm. Abbreviations: cam: cambium, co: collenchyma, pe: periderm, pt: pith. 


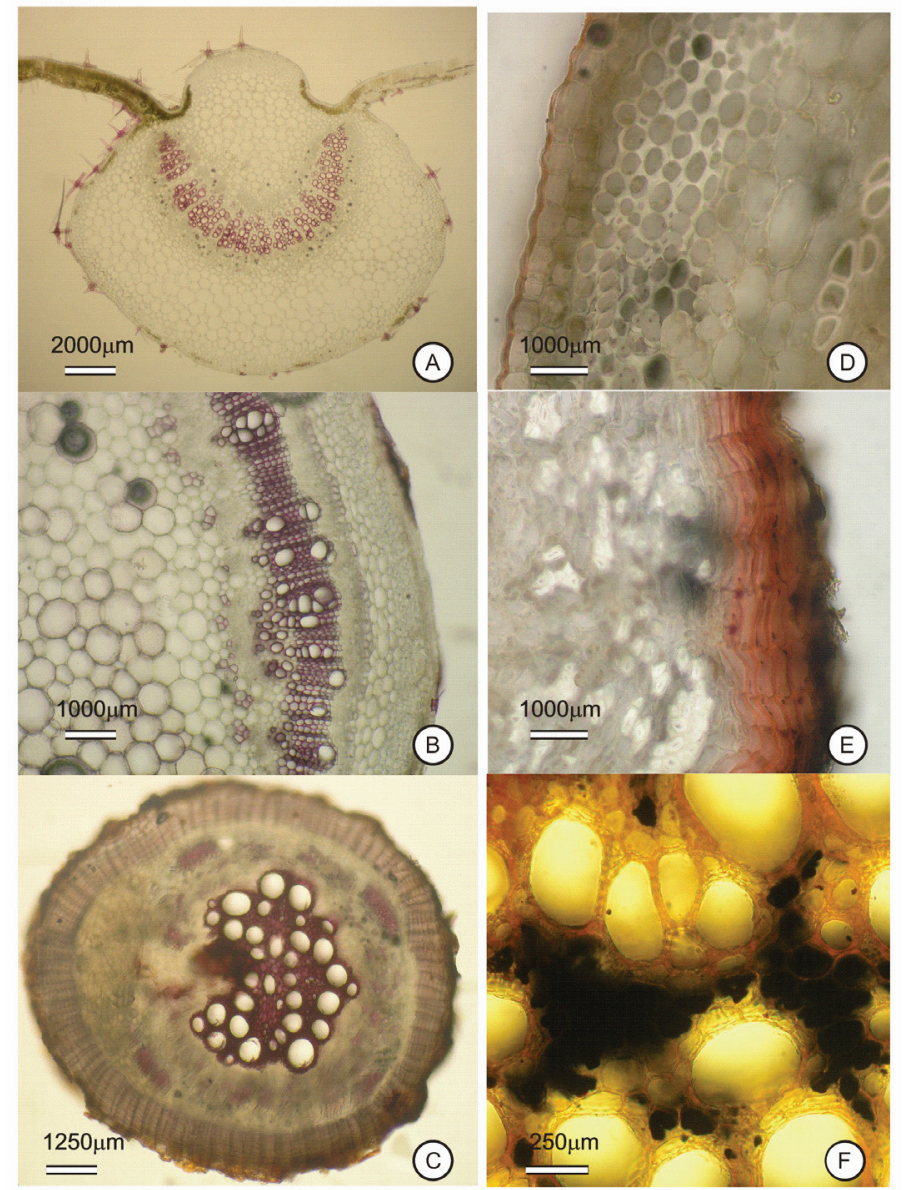

Figure 5. Solanum torvum Sw. (Agra \& Nurit 6758). Histochemical tests in Solanum torvum Sw. (Agra \& Nurit 6758). A-C. Lignified xylem stained by acidified phloroglucinol: A. in midrib; B. in stem; C. in root, in secondary growth, and epidermis suberized; D-E. Sudam III: D. cutinized cell walls in stem; E. periderm in root; F. Starch grains in vascular region stained by lugol.

bundles, collateral, directed to the adaxial surface. The presence of a vascular cambium is evident between the external phloem and the xylem (Figure 3F).

\section{Stem}

In cross section, the stem in secondary growth has practically circular contour and 1-layered epidermis with quadrangular cells, which are coated with a smooth and thin cuticle (Figure 5D), with sessile, subsessile and stalked porrect-stellate trichomes sparse and reduced midpoint. The collenchyma is angular forming a continuous cylinder, 5-8-layered, followed by a reduced cortical parenchyma, 4-5 layered (Figure 4B). The vascularization consists of external phloem, xylem and internal phloem, bounded by a perivascular sheath externally to the phloem. The xylem is lignified (Figure 5B) and positioned as a massive and continuous cylinder, with vessel elements in radial distribution between the lignified fibers (Figure 5B), a 3-4 layered cambial zone is evidenced adjacent to the internal phloem (Figure 4C). The medular parenchyma is formed by thin walls of rounded cells.

\section{Root}

The root, in initial secondary growth (Figure 4D), has an underdeveloped periderm (Figure 5E). The 5-6 layered parenchyma, located between the periderm and phloem, occupies about $40 \%$ of diameter. In the central cylinder is observed a pericycle and 4-5 layers of cambial zone. The secondary phloem and xylem form a massive cylinder, although a tetrarch structure can be verified.

In terminal secondary growth (Figure 4E), the root shows a developed periderm, 12-18 layered. Idioblasts bearing druses of calcium oxalate occur in the parenchyma, below the periderm (Figure 4F), as well as starch grains also occur in parenchyma and vascular region (Figure $5 \mathrm{~F})$.

\section{Discussion}

Morphologically, Solanum torvum resembles $S$. paniculatum, mainly during the juvenile phase of the plant showing large leaves with ovate to ovate-elliptic and strongly ovate or repand blades. However, in a detailed 
analysis these similarities are found to be superficial, since S. torvum has distinctive morphological characters such as ochraceous indument which contrast with the cinereous to canescent indument, referred by Nurit-Silva et al. (2007b) to $S$. paniculatum.

In comparison with other species of Solanum sect. Torva such as S. scuticum Nee, S. adspersum Witasek and S. guaraniticum A. St.-Hil. (Mentz et al., 2000), S. paniculatum (Nurit-Silva et al., 2007b), and $S$. variabile Mart. (Furlan et al., 1999), the leaf morphology including the indument is distinctive to $S$. torvum, besides the reproductive characters. In relation to the trichome morphology, the type porrect-stellate, sessile or stalked, is characteristic to the section and is referred by Mentz et al. (2000) to S. scuticum, S. adspersum and S. guaraniticum, and by Nurit-Silva et al. (2007b) to S. paniculatum, and by Furlan et al. (1999) to $S$. variabile.

In many aspects, the leaf anatomy of $S$. torvum corresponds to the pattern registered to the Solanaceae family and to the genus Solanum by Metcalfe \& Chalk (1950), such as the dorsiventral mesophyll and the angular collenchyma, characters also found in other species of Solanum sect. Torva by Nurit-Silva et al. (2007b), Furlan et al. (1999) and Lima et al. (2009).

The epidermis with wavy anticlinal walls on adaxial surface is similar to described to $S$. torvum by Ahmad (1964), for other side, is very distinctive from the type found in S. paniculatum by Nurit-Silva et al. (2007b) with straight anticlinal walls on the adaxial surface.

Stomata of the anisocytic type present on the epidermis of $S$. torvum were also referred to many species of Solanum by Ahmad (1964), but this type differs from the anomocytic type observed on the abaxial surface of $S$. paniculatum by Nurit-Silva et al. (2007b).

The leaf midrib shows similar structure to all studied species of Solanum sect. Torva such as $S$. variabile (Furlan et al., 1999; Lima et al., 2009) and S. paniculatum (Nurit-Silva et al., 2007b). The petiole having slowly arched to circular contour differs from the type observed in other species of the section, such as S. paniculatum in which it is biconvex-ribbed (Nurit-Silva et al., 2007b).

The presence of idioblasts having sand cristals in mesophyll of S. torvum constitutes a character common to all species of Solanaceae family. It is present in different genera including Solanum and also in species of different infrageneric categories observed by Cosa et al. (1998), Granada-Chacón \& Benítez de Rojas (2004), Maiti et al. (2002) and Nurit-Silva et al. (2007b). On the other hand, the presence of idioblasts having druses observed in $S$. torvum is rare and uncommon in Solanum species.

The vascular structure of stem corresponds to the pattern referred to the Solanaceae family by Metcalfe \& Chalk (1950), and also observed in other species of Solanum sect. Torva such as S. variabile (Furlan et al., 1999) and S. paniculatum (Nurit-Silva et al., 2007b). The indication of eustelic structure of the stem differs from the type present in S. variabile (Furlan et al., 1999), referred as sifonostelic amphyphloic discontinuous and resembles to the type described to $S$. juvenale (Cosa et al., 1998), $S$. paniculatum and $S$. rhytidoandrum Sendtn. (Nurit-Silva et al., 2007b).

The root organization considered tetrarch is similar to the type registered to $S$. elaeagnifolium Cav. (Cosa et al., 1998) and S. rhytidoandrum, and differs from the hexarch structure of $S$. paniculatum (Nurit-Silva et al., 2007b).

The results of this work as well as other already made by Cosa et al. (1998), Furlan et al. (1999) and NuritSilva et al. (2007b), inter alia, have shown the importance of the morpho-anatomical studies for identification and quality control of the herbal medicines, mainly of the species belonging to genera of great richness of diversity as Solanum.

\section{Conclusion}

The leaf morphology and the anatomy of epidermis and appendages of the leaf, stem and root are parameters characteristic of Solanum torvum and are distinctive from those found in other species of Solanum sect. Torva, mainly Solanum paniculatum, which has been confused and used as a substitute.

\section{Acknowledgments}

The authors thank Prof. Jnanabrata Bhattacharyya for the English revision, and Dulce G. Oliveira for her technical support. The financial support and grants to MFA (PQ), KNS (GD), VPMC and RCS (IC) were provided by the Conselho Nacional de Desenvolvimento Científico e Tecnológico.

\section{References}

Agra MF, Bhattacharyya J 1999. Ethnomedicinal and phytochemical investigation on the Solanum species in the Northeast of Brazil. In Nee M, Symon DE, Lester RN, Jessop JP (eds.). Solanaceae IV. Kew: Royal Botanic Gardens, p. 341-343.

Agra MF 2007. Diversity and distribution of Solanum subgenus Leptostemonum in Brazil. Acta Hortic 745: 31-43.

Ahmad KJ 1964. Epidermal studies in Solanum. Lloydia 27: 243250.

Arthan D, Svasti J, Kittakoop P, Pittayakhachonwut D, Tanticharoen M, Thebtaranonth Y 2002. Antiviral isoflavonoid sulfate and steroidal glycosides from the fruits of Solanum torvum. Phytochemistry 59: 459-463.

Basílio IJLD, Agra MF, Bhattacharyya J 2007. Estudo farmacobotânico das folhas de Solanum paludosum Moric. R. Bras Bioci 5: 651-653.

Berlyn GP, Miksche JP 1976. Botanical microtechinique and cytochemistry. Ames: The Yowa State University Press. 
Bohs L 2005. Major clades in Solanum based on ndhF sequences. In Keating RC, Hollowell VC (eds.). Croat monographs in Systematic Botany from the Missouri Botanical Garden. A festschrift for William G. D'Arcy: the legacy of a taxonomist. St. Louis: Missouri Bot Garden Press 104: 27-49.

Chah KF, Muko KN, Oboegbulem SI 2000. Antimicrobial activity of methanolic extract of Solanum torvum fruit. Fitoterapia 71: 187-189.

Cham BE, Gilliver M, Wilson L 1987. Antitumour effects of glycoalkaloids isolated from Solanum sodomaeum. Planta Med 53: 34-37.

Cham BE, Meares HM 1987. Glycoalkaloids from Solanum sodomaeum are effective in the treatment of skin cancers in man. Cancer Lett 36: 111-118.

Cosa MT, Bruno G, Dottori N 1998. Anatomía de órganos vegetativos en Solanum juvenale y su comparación con S. elaeagnifolium (Solanaceae). An Inst Biol, Univ Nac Autón México, Ser Bot 69: 9-22.

Cuervo AC, Blunden G, Patel AV 1991. Chlorogenone and neochlorogenone from the unripe fruits of Solanum torvum. Phytochemistry 30: 1339-1341.

D’Arcy WG 1973. Solanaceae. In Woodson RE, Schery RW (eds.). Flora of Panama. Ann Missouri Bot Gard 60: 573780.

Dopke W, Nogueiras C, Hess U 1975. On the steroid alkaloid and saponin contents of Solanum torvum. Pharmazie 30: 755 .

Furlan CM, Kato ETM, Oliveira F 1999. Caracterização farmacognóstica da droga e do extrato fluido de Solanum variabile Mart. Parte I. Lecta 17: 9-35.

Granada-Chacón WA, Benítez de Rojas CE 2004. Anatomia foliar de cuatro especies de Solanum L. seccion Acanthophora Dunal en Venezuela. Acta Cient Venez 55: 13-26.

Jensen W 1962. A. Botanical histochemistry: principles and practice. San Francisco: W. H. Freeman \& Co.

Johansen DA 1940. Plant microtechnique. New York: McGrawHill.

Kupchan SM, Barboutis SJ, Knox JR, Lau Cam CA 1965. Betasolamarine: tumor inhibitor isolated from Solanum dulcamara. Science 150: 1827-1828.

Lima VFGAP, Souza IL, Ferreira MS, Hugenschmidt RIC, Silva VS 2009. Estudo anatômico da folha de duas espécies de Solanaceae ocorrentes no núcleo cabuçu (Guarulhos, SP). Rev Inst Flor 2: 117-129.

Maiti RK, Villarreal RL, Treviño VA, Valades-Cerda MC 2002. Some aspects on pharmacognosy of ten species of the family Solanaceae utilized in traditional medicine. Caldasia 24: 317-321.

Mendes AM, Cazares R, Romo J 1970. Components of Solanum torvum. Rev Latino Amer Quim 1: 1-6.

Mentz LA, Oliveira PL, Silva MV 2000. Tipologia dos tricomas das espécies do gênero Solanum (Solanaceae) na região Sul do Brasil. Iheringia Sér Bot 54: 75-106.

Metcalfe CR, Chalk L 1950. Anatomy of the dicotyledons. V. II. Oxford: Oxford University Press.

Metcalfe CR, Chalk L 1979. Anatomy of the dicotyledons. Oxford: Oxford University Press.

Nee M 1999. Synopsis of Solanum in the New Word. In Nee M, Symon DE, Lester RN, Jessop JP (eds.). Solanaceae IV. Advances in biology and utilization. Kew: The Royal Botanic Gardens, p. 233-285.

Nguelefack TB, Mekhfi H, Nguelefack-Mbuyo EP, Afkir S, Dimo T, Legssyer A, Ziyyat A 2007. Hypotensive and anti-aggregant activities of extracts from Solanum torvum (Solanaceae) fruits in rat. Fundam Clin Pharm 21: 30-31.

Nurit-Silva K, Agra MF 2005. Estudo farmacobotânico comparativo entre Nicandra physalodes (L.) Gaertn. e Physalis angulata L. (Solanaceae). Rev Bras Farmacogn 15: 344-351.

Nurit-Silva K, Agra MF, Baracho GS, Basílio IJLD 2007a. Estudo farmacobotânico de folhas de Nicotiana glauca (Solanaceae). Lat Am J Pharm 26: 499-506.

Nurit Silva K, Basílio IJLD, Agra MF 2007b. Estudo farmacobotânico comparativo entre Solanum paniculatum L. e Solanum rhytidoandrum Sendtn. $R$ Bras Bioci 5: 243-245.

Schreiber K, Ripperger H 1968. Solanum alkaloids LXXIV. Isolation of jurubine, neochlorogenin and paniculogenin from Solanum torvum. Kulturpfanze 15: 199-204.

Wiart C, Mogana S, Khalifah S, Mahan M, Ismail S, Buckle M, Narayana AK, Sulaiman M 2004. Antmicrobial screening of plants used for traditional medicine in the state of Perak, Peninsular Malaysia. Fitoterapia 75: 68-73.

Wilkinson HP 1979. The plant surface (Mainly Leaf) Part I: Stomata. In Metcalfe CR, Chalk L (eds.). Anatomy of the dicotyledons. Vol. 1 Oxford: Oxford University Press, p. 97-117.

\section{*Correspondence}

Maria de Fátima Agra

Laboratorio de Tecnologia Farmacêutica Prof. Delby Fernandes de Medeiros, Seção de Botânica, Universidade Federal da Paraíba

Caixa Postal 5009, 58015-970 João Pessoa-PB, Brazil

agramf@1tf.ufpb.br

Tel.: +558332167381 